\title{
Thermal treatment decreases resistance to osimertinib in non-small cell lung cancer through the EGFR/PI3K/AKT pathway
}

\author{
Jian WANG, Xiean LING, Min ZHOU, Guanggui DING, Bin PENG, Jun WAN* \\ Department of Thoracic Surgery, The Shenzhen People's Hospital, The Second Clinical Medicine College of Jinan University, Shenzhen, Guang- \\ dong, China \\ ${ }^{*}$ Correspondence: wanjun622@126.com
}

Received May 6, 2020 / Accepted January 14, 2021

\begin{abstract}
Osimertinib (OSI) resistance commonly occurs during the treatment of non-small-cell lung cancer (NSCLC). This study aims to investigate whether the thermal effects of radiofrequency ablation (RFA) can increase the sensitivity of OSI-resistant NSCLC to OSI treatment and whether OSI effectively inhibits the recurrence of OSI-resistant NSCLC following RFA treatment and improve survival of NSCLC patients. In vitro, OSI-resistant NCI-H1975 (NCI-H1975/OSIR) cells and thermotolerant NCI-H1975/OSIR (NCI-H1975/OSIR-a-h) cells were established using human NSCLC cell line NCI-H1975. Cell viability, apoptosis, sensitivity to OSI, threonine-methionine amino acid substitution at position 790 (T790M) mutation levels, and protein expression of epidermal growth factor receptor (EGFR), phosphatidylinositol 3-kinase (PI3K), protein kinase B (AKT), hypoxia-inducible factor-1 alpha (HIF-1a) were detected using different methods. In vivo, a nude mouse model of metastatic human lung cancer was developed and subjected to RFA treatment. The tumor growth, apoptosis, sensitivity to OSI, expression of EGFR/PI3K/AKT/HIF-1a, and CD34 levels were detected in the micrometastases of the transition zone (TZ) around the central ablation zone, and the reference zone (RZ) far from central ablation zone. NCI-H1975/ OSIR and thermotolerant NCI-H1975/OSIR cell models were successfully established. Thermotolerant NCI-H1975/OSIR cells show higher sensitivity to OSI than NCI-H1975/OSIR cells and NCI-H1975 cells. OSI treatment can inhibit the EGFR/ PI3K/AKT pathway and induce apoptosis in both NCI-H1975 cells and thermotolerant NCI-H1975/OSIR cells, but not in NCI-H1975/OSIR cells. In vivo, RFA treatment increases sensitivity to OSI in NCI-H1975/OSIR cell micrometastases in the TZ but not in the RZ. OSI intervention effectively inhibits the over-proliferation of micrometastases and activation of the EGFR/PI3K/AKT pathway, and induces apoptosis of micrometastases in the TZ, but shows little effects on the micrometastases in the RZ. The thermal effects can increase the sensitivity of OSI-resistant NSCLC cells to OSI through the EGFR/ PI3K/AKT/HIF-1a signaling pathway, indicating that RFA combined with OSI might be a clinically effective and comprehensive therapy for the treatment of OSI-resistant NSCLC.
\end{abstract}

Key words: osimertinib, non-small cell lung cancer, radiofrequency ablation, proliferation, apoptosis, sensitivity, hypoxiainducible factor-1 alpha

Lung cancer is one of the most common and fatal cancers in the world [1]. In China, lung cancer has become the leading cause of cancer deaths since the 1990s [2]. The incidence of lung cancer has increased over the past 20 years and might continue to increase if no effective treatment is developed [3]. In addition, the lung is the second most frequent site of metastasis, and metastases to the lung complicate the course of as many as $40 \%$ of other malignancies [4]. Targeted therapy of epidermal growth factor receptor tyrosine kinase inhibitors (EGFR-TKIs) is regarded as the main first-line treatment for non-small-cell lung cancer (NSCLC) patients with EGFR mutations. Although targeted therapy using first- and second-generation TKIs may lead to longer progression-free survival (PFS) and is better tolerated by patients, long-term treatment inevitably results in drug resistance. More than $50 \%$ of acquired resistance is associated with a threoninemethionine amino acid substitution at position 790 (T790M) mutation [5]. Recently, osimertinib (OSI, also known as AZD9291) is expected to become the standard treatment for advanced NSCLC patients with an EGFR mutation and a documented T790M mutation, who have failed the firstor second-generation EGFR-TKI [6]. However, drug resistance to OSI may occur in most patients due to a substitution mutation (cysteine 797 to serine (EGFR C797S)) at the OSI binding site [7]. Thus, signal-targeted therapy has its limitations, and multimodal therapy is urgently needed.

Recently, treatments of lung cancer via minimally invasive approaches such as radiofrequency ablation (RFA) have 
received great attention. RFA is the most widely adopted thermal ablation method and shows high success rates [8]. Studies suggest that lung tumors are suitable for RFA because the surrounding air in the adjacent normal lung parenchyma provides an insulating effect for concentrating the radiofrequency energy within the tumor tissue [9]. However, tumor recurrence is common, especially in an incomplete RFA treatment. We previously found that lung cancer frequently recurs around the ablation zone. In this area, the residual lung cancer cells acquire thermotolerance and transform into heatadapted cells. The proliferation of heat-adapted subtype cells is accelerated by hypoxia-inducible factor-1 alpha (HIF-1a) expression, leading to tumor recurrence [10]. Some studies have shown that RFA during TKI treatment can significantly inhibit tumor growth, and prolong PFS and overall survival (OS) of patients $[11,12]$, but others have questioned whether RFA will decrease drug resistance rate and improve the therapeutic efficacy of effective systemic treatment [13]. Therefore in this study, we investigated whether the combination of RFA + OSI treatment would overcome drug resistance and improve therapeutic effects in OSI-resistant NSCLC.

\section{Materials and methods}

Cell culture. NSCLC NCI-H1975 cells (EGFR T790M mutation) were obtained from the Shanghai Cell Bank (Shanghai, China). Cells were maintained in the Roswell Park Memorial Institute (RPMI)-1640 medium (Sigma-Aldrich, St. Louis, MO, USA) supplemented with $10 \%$ fetal bovine serum (FBS), $100 \mathrm{U} / \mathrm{ml}$ penicillin, and $100 \mu \mathrm{g} / \mathrm{ml}$ kanamycin at $37^{\circ} \mathrm{C}$ in a humidified atmosphere containing $5 \% \mathrm{CO}_{2}$ and $20 \% \mathrm{O}_{2}$. The medium was routinely changed every 2-3 days after seeding. Cells were digested with trypsin/ethylene diamine tetraacetic acid (EDTA) (GibcoBRL, Paisley, UK), and resuspended in serum-free RPMI-1640 medium to a final concentration of approximately $5 \times 10^{5}$ cells $/ 10 \mu \mathrm{l}$.

Establishment of OSI-resistant NCI-H1975 cells. OSI-resistant NCI-H1975 (NCI-H1975/OSIR) cells were established according to the previous study [14]. Briefly, NCI-H1975 cells were treated with $0.03 \mu \mathrm{M}$ OSI (Aladdin Industrial Corporation, Shanghai, China) for $72 \mathrm{~h}$, and then incubated in a drug-free medium until the surviving cells had recovered and shown a normal exponential growth rate. The cycles of selection were tested in the presence of gradually increased concentrations of OSI from $0.03-1.5 \mu \mathrm{M}$. After approximately 6 months, cells became resistant to OSI. Surviving cells were harvested and propagated in a drug-free medium. The $21^{\text {st }}$ passage cells were named NCI-H1975/ OSIR and used in the present study. The parental NCI-H1975 cells were cultured in a drug-free medium in parallel.

Establishment of thermotolerance NCI-H1975/OSIR cells. The NCI-H1975/OSIR cells were seeded on cell culture plates, sealed with parafilm, and submerged in a water bath at the desired temperature for $10 \mathrm{~min}$. Eight temperatures matching the ablation temperatures applied during the clinical treatment of lung cancer were selected: $40^{\circ} \mathrm{C}, 41^{\circ} \mathrm{C}$, $42^{\circ} \mathrm{C}, 43^{\circ} \mathrm{C}, 44^{\circ} \mathrm{C}, 45^{\circ} \mathrm{C}, 46^{\circ} \mathrm{C}$, and $47^{\circ} \mathrm{C}$. After the hyperthermic treatment, a fresh culture medium was added to each well, and the surviving cells were maintained at $37^{\circ} \mathrm{C}$ with an atmosphere containing $5 \% \mathrm{CO}_{2}$ and $20 \% \mathrm{O}_{2}$. Then, these cells were separately cultured under 8 desired temperature points $\left(40-47^{\circ} \mathrm{C}\right)$ and utilized as 8 sublines (marked in turn of increasing temperature as NCI-H1975/OSIR-a-h).

Cell viability assays. Cells were cultured at a concentration of $1 \times 10^{4}$ cells/well in 48 -well plates to analyze viability using 3-[4,5- dimethylthiazol-2-yl]-2,5- diphenyltetrazolium bromide (MTT) assay. MTT solution (Sigma-Aldrich, St. Louis, MO, USA) was added to each well at a final concentration of $0.5 \mathrm{mg} / \mathrm{ml}$ and incubated for $4 \mathrm{~h}$. At the end of the incubation, formazan crystals resulting from MTT reduction were dissolved by the addition of $150 \mu \mathrm{l} /$ well dimethylsulfoxide (DMSO). The optical density (OD) was read at $570 \mathrm{~nm}$, and the average values were determined from replicate wells.

Annexin V-FITC and PI staining assays. Apoptosis of cells was detected by the Annexin V-FITC/PI apoptosis detection kit (BioVision, CA, USA), according to the manufacturer's instructions. Briefly, after incubation with OSI $(1.0 \mu \mathrm{M})$ for 48 h, NCI-H1975, NCI-H1975/OSIR, and NCI-H1975/ OSIR-h sublines were trypsinized, washed, and collected. Cells were then resuspended in binding buffer and stained with Annexin-FITC and propidium iodide (PI) solution for $30 \mathrm{~min}$. A total of $1.0 \times 10^{5}$ cells were collected and analyzed by a flow cytometer (FACS-Canto, BD Bioscience, USA).

Immunohistochemical staining assay. Paraffinembedded samples were analyzed for DNA fragmentation using a terminal deoxynucleotidyl transferase (TdT)mediated dUTP nick end labeling (TUNEL) assay with the in-situ Cell Death Detection Kit (Sigma-Aldrich, St. Louis, MO, USA). According to the manufacturer's protocol, $3 \mu \mathrm{m}$ thick paraffin sections of the tissues were deparaffinized in xylene and rehydrated in decreasing concentrations of ethanol. The sections were rinsed and incubated in $3 \%$ hydrogen peroxide in methanol for 5 min to block endogenous peroxidase activity. Tissue sections were then incubated in $20 \mu \mathrm{g} / \mathrm{ml}$ proteinase $\mathrm{K}$ for $15 \mathrm{~min}$, washed with phosphate buffer saline (PBS), incubated in equilibration buffer, and then in TdT enzyme solution in a humidified chamber at $37^{\circ} \mathrm{C}$ for $60 \mathrm{~min}$. The sections were rinsed and incubated with a streptavidin-peroxidase (Vector Laboratories, Burlingame, CA, USA) conjugate for $30 \mathrm{~min}$. Peroxidase activity was detected by application of 3,3'-diaminobenzidine (DAB). Apoptotic activity was identified by a dark brown nuclear stain and observed under a light microscope (Olympus, Tokyo, Japan).

Analysis of T790M mutation level. Previous studies verified that the loss of EGFR due to a T790M mutation was the main cause of resistance to third-generation EGFR-TKIs, such as OSI [15]. NCI-H1975 cells with the EGFR T790M mutation were cultured at $37^{\circ} \mathrm{C}$ and treated as the control group. The relative quantification of T790M mutation level in 
parental NCI-H1975/OSIR cells and $40-47^{\circ} \mathrm{C}$ heat-adapted sublines were analyzed by real-time polymerase chain reaction (PCR) using SYBR ExScript RT-PCR Kit according to the manufacturer's protocol (Takara Biotechnology Co. Ltd., Dalian, China) on an iCycler Real-Time PCR Detection System (Bio-Rad Laboratories, Hercules, CA). All the DNA samples were extracted according to the manufacturer's protocol and the concentrations were measured. Then, the extracted DNA samples were diluted with ultrapure water to a final concentration of $2 \mathrm{ng} / \mu \mathrm{l}$. All the steps were performed in accordance with a diagnostic kit for mutations in the Human EGFR Gene (Amoy Diagnostics Co., Ltd Xiamen, China). The relative quantitation of the T790M mutation was analyzed by the $2-{ }^{-} \mathrm{CT}$ method. PCR primer sequences for T790M were 5'-CCTCCTGGCAGCTCATCGT-3' (forward) and 5'-TGTTCCCGGACATAGTCCAGG-3' (reverse). The thermal cycling conditions were as follows: first stage- 1 cycle of $95^{\circ} \mathrm{C}$ for $5 \mathrm{~min}$, second stage- 15 cycles of $95^{\circ} \mathrm{C}$ for $25 \mathrm{~s}$, $64^{\circ} \mathrm{C}$ for $20 \mathrm{~s}$, and $72^{\circ} \mathrm{C}$ for $20 \mathrm{~s}$, and third stage- 31 cycles of $93^{\circ} \mathrm{C}$ for $25 \mathrm{~s}, 60^{\circ} \mathrm{C}$ for $35 \mathrm{~s}$, and $72^{\circ} \mathrm{C}$ for $20 \mathrm{~s}$. $\beta$-actin was used as an internal control.

Animals and surgical procedures. A nude mouse model with metastatic human lung cancer was constructed as previously described [10]. Male congenital athymic BALB/c nude mice at 6-8-weeks of age weighting 16-22 g were obtained from the Experimental Animal Center of the Anhui Medical University, China, and maintained under pathogen-free conditions in accordance with established Institutional Guidance and Approved Protocols. Animals were housed under standard laboratory conditions. All surgical procedures were performed under isoflurane inhalation anesthesia. Buprenorphine was injected intramuscularly prior to surgery for perioperative analgesia. All animals were acclimated for at least 7 days prior to an intravenous (i.v.) injection of green fluorescent protein (GFP)-labeled NCI-H1975/OSIR. On day 1, cells were collected and resuspended in PBS (Thermo Fisher Scientific, MA, USA) to obtain a concentration of $5 \times 10^{7}$ cells $/ \mathrm{ml}$. Tail vein injection of $100 \mu \mathrm{l}$ of cell solution was given to each mouse. Seven days after injection, tumor metastasis was monitored by in vivo imaging. Chloral hydrate $(100 \mu \mathrm{l})$ was administered by intraperitoneal (i.p.) injection and the procedure commenced after $5 \mathrm{~min}$. After anesthesia, images of mice were taken once every $3 \mathrm{~min}$ using an IVIS Lumina II in vivo imaging system (Caliper Life Sciences, a PerkinElmer Company, Hopkinton, MA, USA), and collected for further analysis. For intervention studies, 20 mice with established micrometastases were given RFA treatment and randomly divided into 2 groups $(\mathrm{n}=10$ each): RFA group, nude mice only received RFA, and RFA + OSI group, nude mice received RFA combined with injection of $60 \mu \mathrm{M} /$ day OSI. Micrometastases growth was assessed on day 14 following RFA treatment. The tumor was assayed as previously described [16]. Tumor load in the lung was scored as the pneumonic replacement area (PRA), which was the percentage of lung tissue that had been replaced by tumor tissue. PRA in the transition zone (TZ) was measured and defined as the area stretching $2-5 \mathrm{~mm}$ outside the necrotic central area. PRA in the reference zone (RZ) was defined as the remaining part of the ipsilateral lung tissue. The PRA values in the TZ and RZ were analyzed and calculated in both the RFA group and the RFA + OSI group. All blind analyses were performed by at least 2 independent observers who had at least three years of clinical experience. Ten mice with metastatic human lung cancer receiving no treatments were used as the control.

Ethical approval was obtained from the Medical Ethics Committee of Anhui Medical University with the following reference number: LLSC2013030. All animal experiments were conducted in accordance with the 1975 Declaration of Helsinki as well as the protocols approved by the Medical Ethics Committee.

Western blot analysis. Western blot analysis was used to evaluate protein expression of phosphorylated EGFR (p-EGFR) Tyr1068, AKT, phosphorylated AKT (p-AKT) Ser473, B-cell lymphoma-2 (Bcl-2), Bcl-2-associated X Protein 1 (Bax-1), CD34, and HIF-1a, as described in our previous study [10]. The primary antibodies, p-EGFR (Tyr1068) (Cat. No. 14565; 1:200 dilution), EGFR (Cat. No. 6627; 1:200 dilution), p-AKT (Ser473) (Cat. No. 9271; 1:1,000 dilution), AKT (Cat. No. 9272; 1:1,000 dilution), Bcl-2 (Cat. No. 3498; 1:50 dilution), Bax-1 (Cat. No. 2772; 1:1,000 dilution), HIF-1a (Cat. No. 14179; 1:500 dilution), and the respective secondary antibodies were purchased from Cell Signaling Technology, Beverly, MA, USA. Anti-CD34 (Cat. No. 3569; 1:50 dilution) was purchased from Boster Biological Engineering Technology Limited Company, Wuhan, China.

Immunohistochemistry detection for CD34 expression in tumor tissues. All tumor tissues were cut into $4 \mu \mathrm{m}$ slices, deparaffinized, and treated with $0.3 \%$ hydrogen peroxide in methanol for $30 \mathrm{~min}$. Sections were treated with $0.05 \%$ protease XIV for $5 \mathrm{~min}$ at $37^{\circ} \mathrm{C}$ for antigen retrieval and then incubated with a CD34 primary antibody (Cat. No. BA3414; 1:200 dilution; Wuhan Boster Biological Engineering Technology Co. Ltd., Wuhan, China) overnight at $4^{\circ} \mathrm{C}$. The sections were then incubated with a biotin-conjugated goat anti-mouse secondary antibody (Cat. No. BA1001; 1:1000; Wuhan Boster Biological Engineering Technology Co. Ltd., Wuhan, China) at room temperature for $45 \mathrm{~min}$. The sections were subsequently incubated with a streptavidin-biotinperoxidase complex (Vectastain ABC kit, Vector Laboratories, Burlingame, CA, USA) at room temperature for $45 \mathrm{~min}$. The reaction was visualized using chromogen DAB for 10 s. Finally, the slides were counterstained with hematoxylin, mounted, and examined on a Nikon Eclipse Ti microscope with a $400 \times$ objective. HIF-1a expression and microvessel density (MVD) were defined as the number of positively stained vessels per high-power field of view (HPF).

Statistical analysis. All data were represented as mean \pm standard deviation (SD) of three independent experiments 
and analyzed using Statistical Product and Service Solutions (SPSS) 13.0 software (SPSS, Inc., Chicago, IL, USA). Independent-sample $t$-tests were used to evaluate the differences in OD values. The median inhibition concentration (IC50) of OSI was calculated by GraphPad Prism 5 software (GraphPad Software, Inc., San Diego, CA, USA). Resistance index (RI) was calculated as the ratio of IC50 value between NCI-H1975/OSIR and parental NCI-H1975 cells. A p-value $<0.05$ was considered statistically significant.

\section{Results}

Establishment of NCI-H1975/OSIR cells. NCI-H1975/ OSIR cells were established from NCI-H1975 cells through incubation in a medium containing OSI at different concentrations $(0.03 \mu \mathrm{M}$ to $1.5 \mu \mathrm{M})$ for about 6 months. To detect whether NCI-H1975/OSIR cells were successfully established, MTT assays were performed to detect cell viability

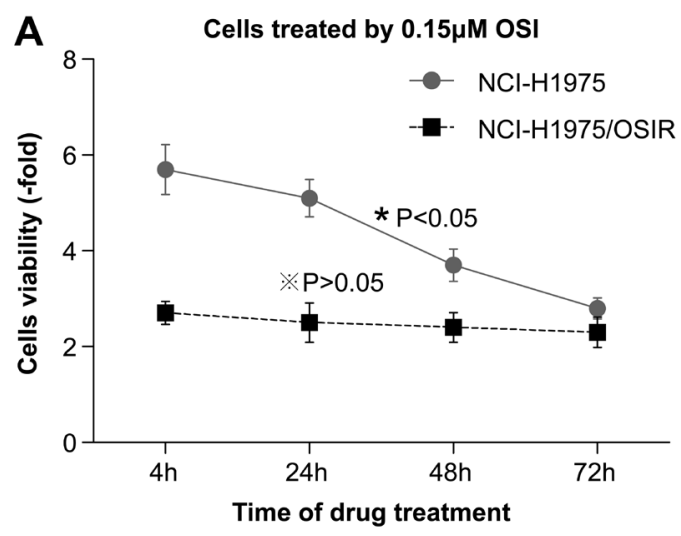

B Cell viability of cells in different treatment groups

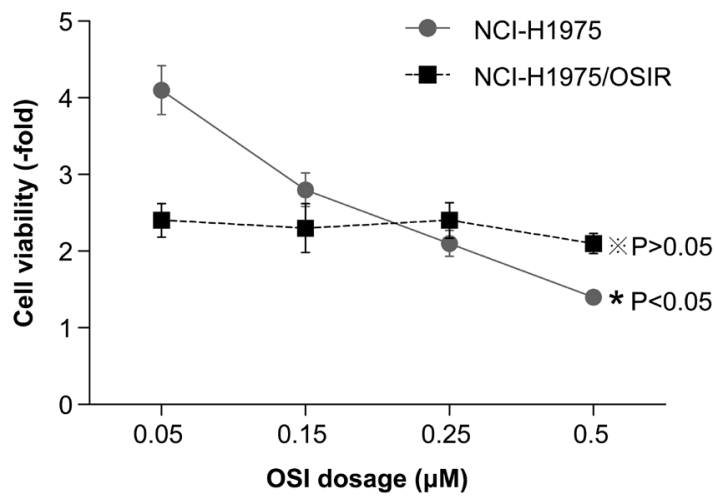

Figure 1. Establishment of NCI-H1975/OSIR cells. A) NCI-H1975/OSI cells, cell viabilities of NCI-H1975 and NCI-H1975/OSIR cells were detected by MTT assays following $0.15 \mu \mathrm{M}$ OSI treatment from 4-72 $\mathrm{h}$ ( ${ }^{*}$ p $>0.05$ NCI-H1975/OSIR cells: 4 h vs. 24 h, 24 h vs. 48 h, 48 h vs. 72 h; ${ }^{*}$ p $<0.05$ NCI-H1975 cells: 4 h vs. 24 h, 24 h vs. 48 h, 48 h vs. 72 h) B) The viabilities of NCI-H1975 and NCI-H1975/OSIR cells were detected by MTT assays after treatment with $0.05 \mu \mathrm{M}, 0.15 \mu \mathrm{M}, 0.25 \mu \mathrm{M}$ and $0.5 \mu \mathrm{M}$ OSI for $72 \mathrm{~h}\left({ }^{*} \mathrm{p}>0.05 \mathrm{NCI}-\mathrm{H} 1975 / \mathrm{OSIR}\right.$ cells: $0.05 \mu \mathrm{M}$ vs. $0.15 \mu \mathrm{M}, 0.15$ $\mu \mathrm{M}$ vs. $0.25 \mu \mathrm{M}, 0.25 \mu \mathrm{M}$ vs. $0.5 \mu \mathrm{M} ;{ }^{\star} \mathrm{p}<0.05 \mathrm{NCI}-\mathrm{H} 1975$ cells: $0.05 \mu \mathrm{M}$ vs. $0.15 \mu \mathrm{M}, 0.15 \mu \mathrm{M}$ vs. $0.25 \mu \mathrm{M}, 0.25 \mu \mathrm{M}$ vs. $0.5 \mu \mathrm{M})$. of NCI-H1975 and NCI-H1975/OSIR cells following OSI treatment at concentrations of $0.05 \mu \mathrm{M}, 0.15 \mu \mathrm{M}, 0.25 \mu \mathrm{M}$, $0.5 \mu \mathrm{M}$ for $72 \mathrm{~h}$, or $0.15 \mu \mathrm{M}$ for $4 \mathrm{~h}, 24 \mathrm{~h}, 48 \mathrm{~h}$, and $72 \mathrm{~h}$. After exposure to $0.15 \mu \mathrm{M}$ OSI for $72 \mathrm{~h}$, cell viability of NCI-H1975 cells decreased significantly $(p<0.05)$, but cell viability of NCI-H1975/OSIR cells did not change obviously ( $\mathrm{p}>0.05$; Figure 1A). The IC50 values of OSI for NCI-H1975 and NCI-H1975/ OSIR cells were $0.039 \pm 0.012 \mu \mathrm{M}$ and $3.578 \pm 0.672 \mu \mathrm{M}$, respectively, and RI was $70.08 \pm 18.92$. In addition, it was found that after treatment with $0.05 \mu \mathrm{M}$, $0.15 \mu \mathrm{M}, 0.25 \mu \mathrm{M}$, and $0.5 \mu \mathrm{M}$ OSI for $72 \mathrm{~h}$, the colonyforming abilities of NCI-H1975 cells significantly decreased $(\mathrm{p}<0.05)$, but the colony-forming abilities of NCI-H1975/ OSIR cells showed little changes ( $>>0.05$; Figure $1 \mathrm{~B})$.

The resistance of thermotolerant NCI-H1975/OSIR cells to OSI was decreased. To detect the potential effects of thermal treatment on the proliferative activity of NCI-H1975/ OSIR cells, NCI-H1975/OSIR cells were adapted to various
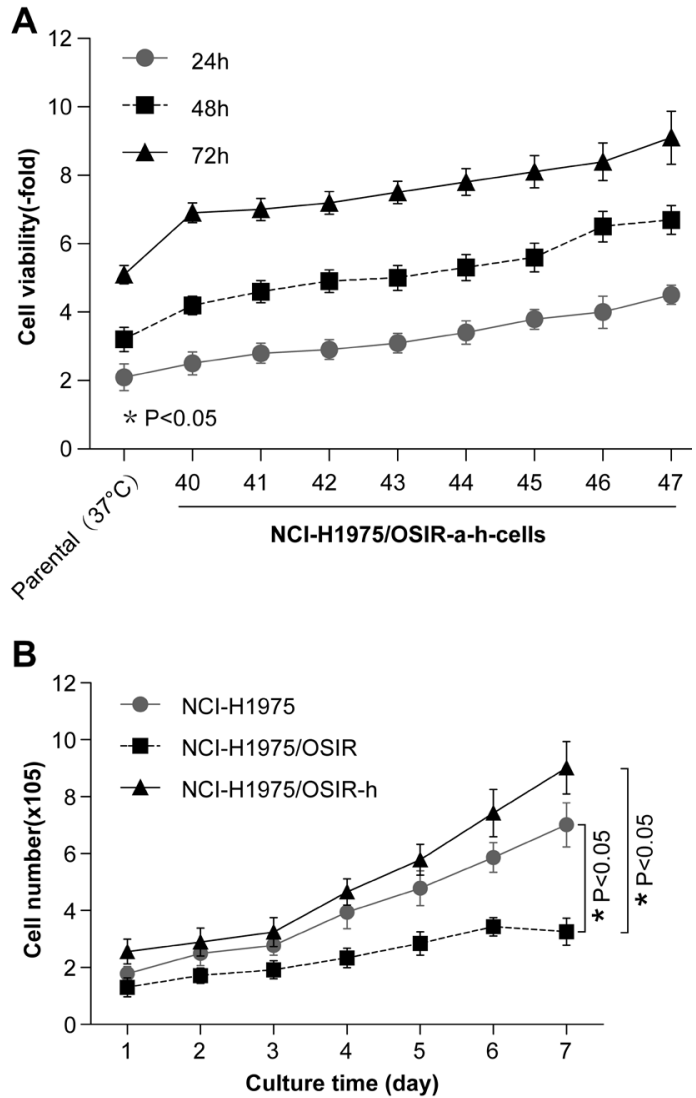

Figure 2. The viability of NCI-H1975/OSIR cells adapted to different temperatures. A) The viability of parental NCI-H1975/OSIR and NCIH1975/OSIR-a-h cells incubated at $40-47^{\circ} \mathrm{C}$ for 5 min was detected by MTT assays at 24,48 , and $72 \mathrm{~h}\left({ }^{*} \mathrm{p}<0.05\right.$ parental NCI-H1975/OSIR cells vs. NCI-H1975/OSIR-a-h cells). B) A growth curve of parental NCIH1975 and NCI-H1975/OSIR cells, NCI-H1975/OSIR-h was drawn. Data are the representative results of three independent experiments $\left({ }^{\star} \mathbf{p}<0.05\right.$ from days 2-7 parental NCI-H1975 cells vs. NCI-H1975/OSIR cells; ${ }^{*} \mathrm{p}<0.05$ from days 2-7 NCI-H1975/OSIR cells vs. NCI-H1975/OSIR-h). 
kinds of temperatures $\left(37^{\circ} \mathrm{C}, 40^{\circ} \mathrm{C}, 41^{\circ} \mathrm{C}, 42^{\circ} \mathrm{C}, 43^{\circ} \mathrm{C}, 44^{\circ} \mathrm{C}\right.$, $45^{\circ} \mathrm{C}, 46^{\circ} \mathrm{C}, 47^{\circ} \mathrm{C}$ ), and cell viability was assessed at $24 \mathrm{~h}, 48$ $\mathrm{h}$, and $72 \mathrm{~h}$ after thermal treatment. It was suggested that cell viability of these sublines was promoted compared to cells cultured at $37^{\circ} \mathrm{C}(\mathrm{p}<0.05)$, and the effect in NCI-H1975/ OSIR-h cells cultured at $47^{\circ} \mathrm{C}$ was more significant, indicating the successful establishment of thermotolerant NCI-H1975/OSIR cells (Figure 2A). Next, the differences in proliferation activity among NCI-H1975 cells, NCI-H1975/ OSIR cells, and NCI-H1975/OSIR-h cells were monitored after treatment with OSI and found that NCI-H1975/ OSIR-h cells exhibited a significantly higher proliferation rate compared to NCI-H1975/OSIR and NCI-H1975 cells $(\mathrm{p}<0.05)$, indicating that NCI-H1975/OSIR-h cells were more sensitive to OSI than NCI-H1975 cells and NCI-H1975/ OSIR cells (Figure 2B). Then, the relative T790M mutation levels were analyzed by RT-PCR and the results showed that compared to NCI-H1975/OSIR cells cultured at $37^{\circ} \mathrm{C}$, the T790M mutation level was promoted with the increase of temperatures. NCI-H1975/OSIR-h cells cultured at $47^{\circ} \mathrm{C}$ had the highest T790M mutation level among the 8 sublines $(\mathrm{p}<0.05$; Figure $3 \mathrm{~A})$. Furthermore, compared to NCI-H1975/ OSIR cells cultured at $37^{\circ} \mathrm{C}$, RI in NCI-H1975/OSIR sublines $\mathrm{a}-\mathrm{h}$ was decreased with the increase of temperatures, and NCI-H1975/OSIR-h cells showed the lowest resistance to OSI $(p<0.05$; Figure $3 \mathrm{~B})$. These data suggest that thermotolerant NCI-H1975/OSIR cells, particularly NCI-H1975/ OSIR-h cells acquire the thermotolerance with the increased sensitivity to OSI.

OSI inhibited the EGFR/PI3K/AKT pathway and induced apoptosis in thermotolerant NCI-H1975/OSIR cells. Western blot results suggested that NCI-H1975/ OSIR-h cells cultured at $47^{\circ} \mathrm{C}$ exhibited significantly higher protein expression levels of p-EGFR and total EGFR, Akt, p-Akt, and HIF-1a than both NCI-H1975/OSIR and NCI-H1975 cells cultured at $37^{\circ} \mathrm{C}(\mathrm{p}<0.05$; Figures $4 \mathrm{~A}$, 4B). With OSI intervention, EGFR, p-EGFR, AKT, p-AKT, and HIF-1a expression levels were significantly inhibited in both NCI-H1975/OSIR-h cells and parental NCI-H1975/ OSIR cells $(\mathrm{p}<0.05$; Figures $4 \mathrm{~A}, 4 \mathrm{~B})$. However, these protein expression patterns showed little changes in NCI-H1975/ OSIR cells with OSI intervention ( $p>0.05$; Figures $4 \mathrm{~A}, 4 \mathrm{~B})$. Therefore, we concluded that the upregulation of EGFR expression might contribute to the high sensitivity to OSI. OSI significantly inhibited the p-AKT and HIF-1a expression in the NCI-H1975/OSIR-h cells under higher temperature, but not in NCI-H1975/OSIR cells. It was also found that OSI could induce the apoptosis of NCI-H1975 and NCI-H1975/ OSIR-h, but not NCI-H1975/OSIR cells ( $\mathrm{p}>0.05$; Figures 4C, 4D). After the intervention with OSI, the apoptosis rate of NCI-H1975/OSIR-h cells was significantly increased in comparison with NCI-H1975/OSIR cells $(p<0.05)$. The apoptosis rate of NCI-H1975/OSIR-h was also promoted compared with NCI-H1975 cells after intervention with OSI $(\mathrm{p}<0.05$; Figures 4C, 4D). We speculated that NCI-H1975/
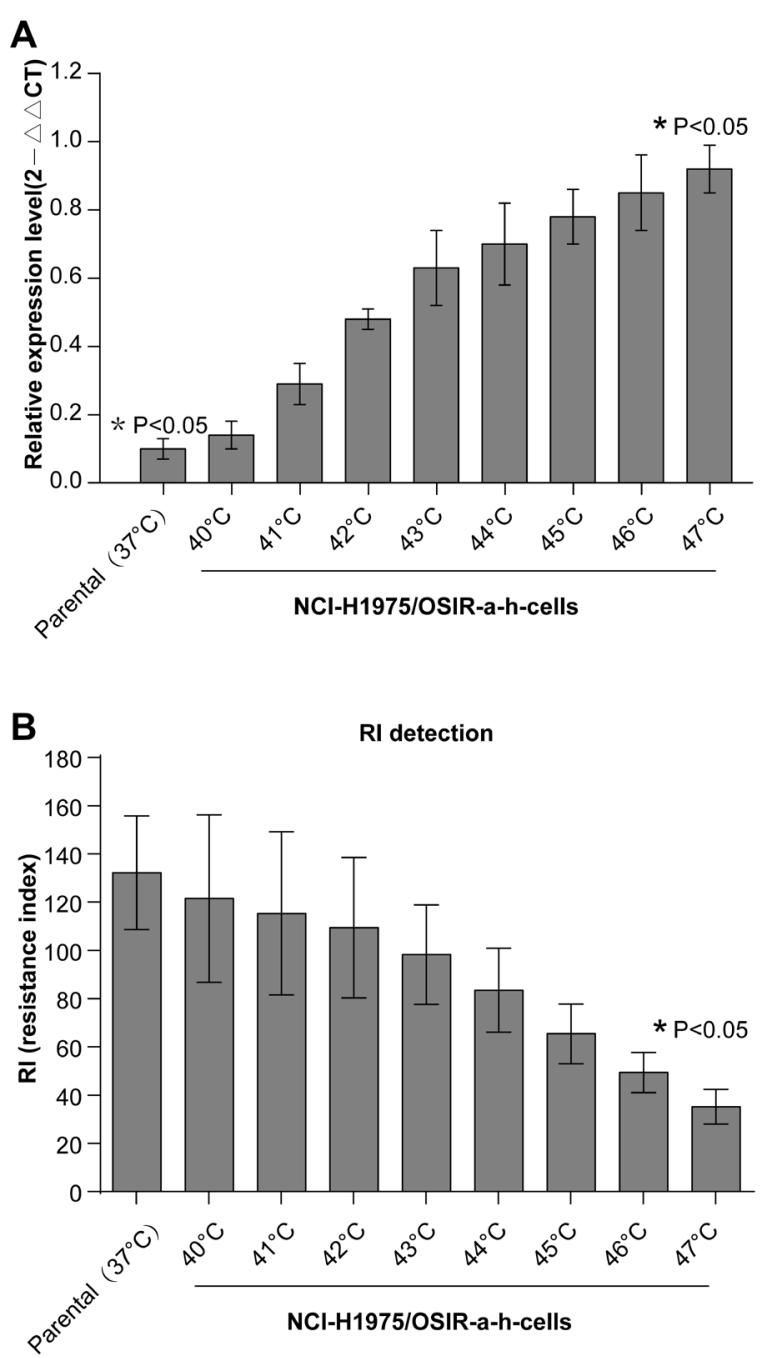

Figure 3. The resistance of thermotolerant NCI-H1975/OSIR cells to OSI is decreased. A) T790M mutation levels were detected in NCI-H1975/ OSIR-a-h cells $\left({ }^{*}\right.$ p $<0.05$, parental NCI-H1975/OSIR cells vs. NCI-H1975/ OSIR-a-h cells). B) The resistance index (RI) of parental NCI-H1975/ OSIR cells and NCI-H1975/OSIR-a-h cells $\left({ }^{\star} \mathrm{p}<0.05\right.$, NCI-H1975/OSIR-h cells vs. parental NCI-H1975/OSIR cells and the others sublines).

OSIR-h cells exposed to higher temperatures were more sensitive to OSI than parental NCI-H1975 cells cultured at $37^{\circ} \mathrm{C}$. In this study, OSI significantly inhibited $\mathrm{Bcl}-2$ protein expression and upregulated Bax-1 protein expression in both NCI-H1975/OSIR-h cells and NCI-H1975 cells ( $p>0.05$ ). However, OSI had little effect on Bcl-2 and Bax-1 expression in NCI-H1975/OSIR cells $(\mathrm{p}<0.05)$. After intervention with OSI, the expression of Bcl-2 was lower in NCI-H1975/ OSIR-h cells than NCI-H1975/OSIR and NCI-H1975 cells. The expression of Bax-1 was higher in NCI-H1975/ OSIR-h cells than NCI-H1975/OSIR and NCI-H1975 cells (Figures $4 \mathrm{E}, 4 \mathrm{~F}$ ). These results suggest that OSI inhibits the EGFR/PI3K/AKT pathway and induces apoptosis in thermotolerant NCI-H1975/OSIR cells. 


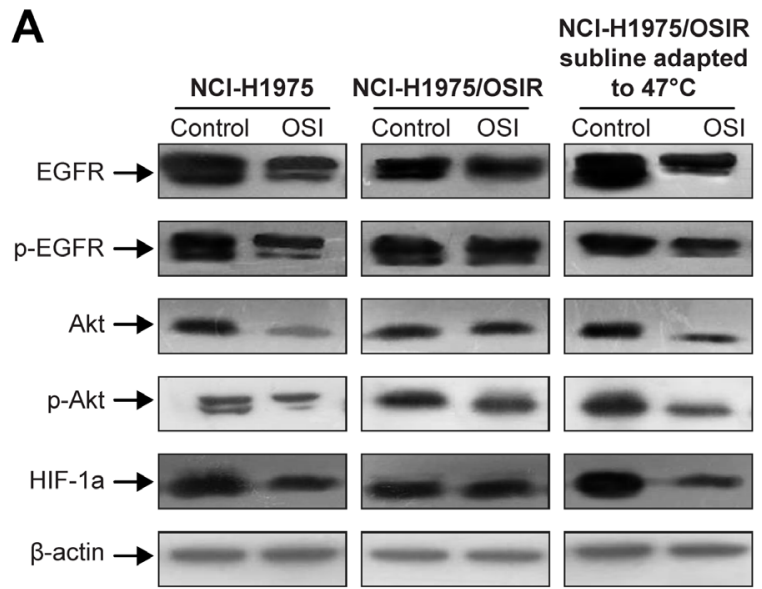

C
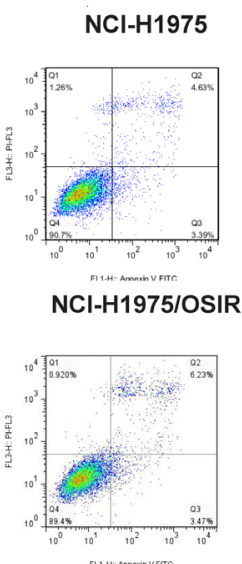

NCI-H1975/OSIR-h

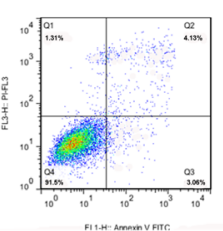

D

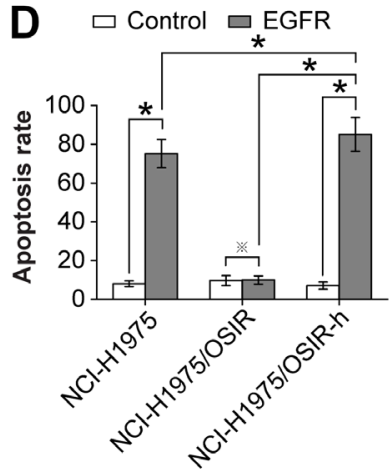

B EGFR expression level
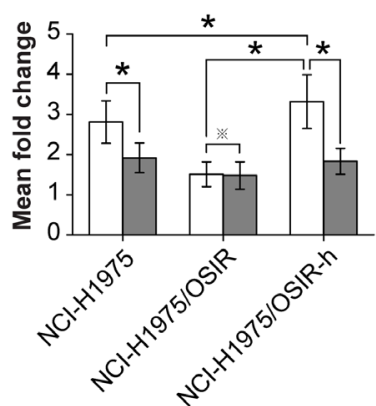

Akt expression level $\square$ Control $\square$ OSI
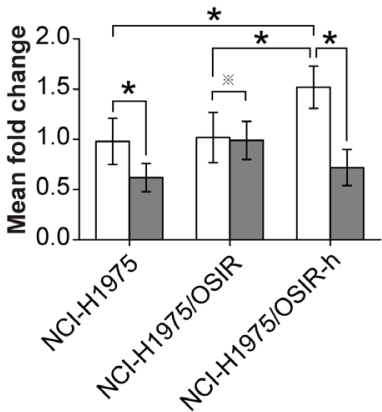

HIF-1a expression level $\square$ Control $\square$ OSI

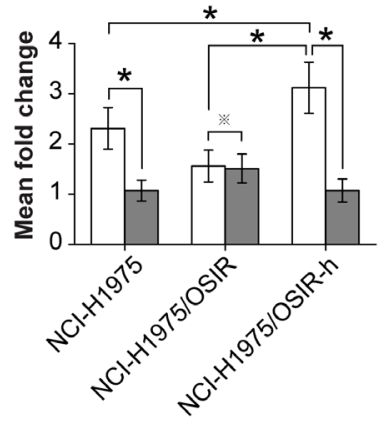

NCl-H1975/OSIR subline adapted
E

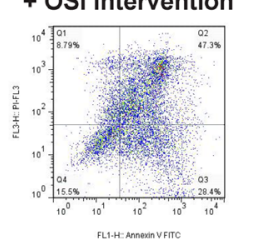

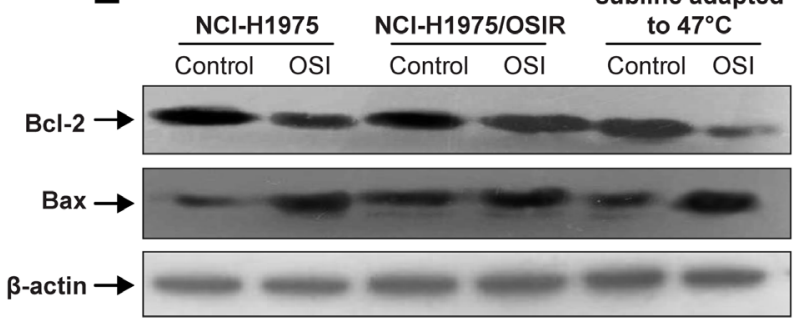

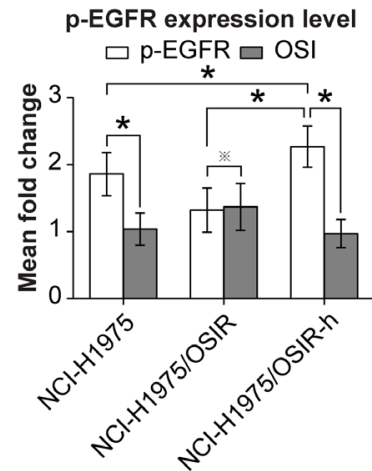

p-Akt expression level $\square$ Control $\square$ OSI
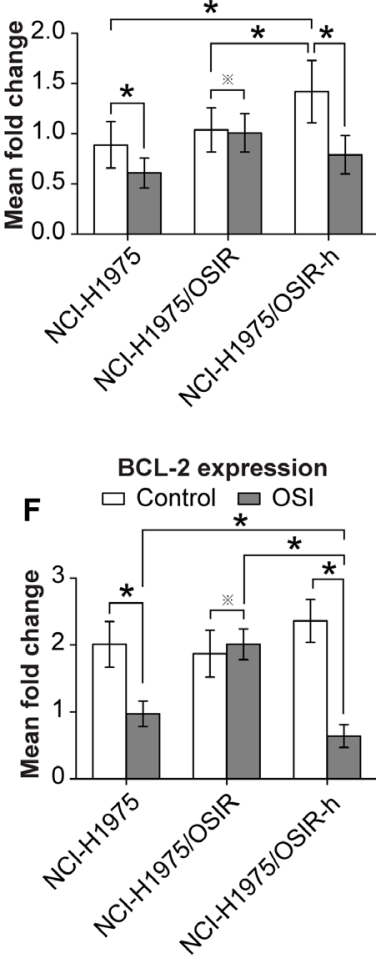

Bax expression $\square$ Control * $\square$ OSI

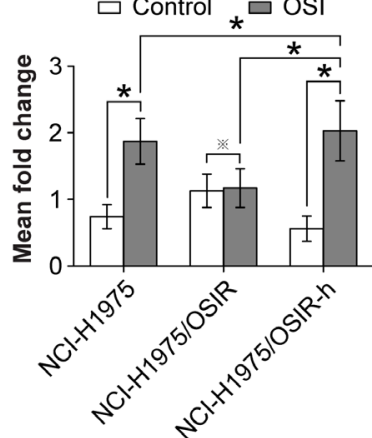

Figure 4. OSI inhibits the EGFR/PI3K/AKT pathway and induces apoptosis in thermotolerant NCI-H1975/OSIR cells. A) The expression level of EGFR, p-EGFR, AKT, p-AKT, and HIF-1a in parental NCI-H1975 cells, NCI-H1975/OSIR cells, and NCI-H1975/OSIR-h treated with or without OSI $(0.5 \mu \mathrm{M})$ for $72 \mathrm{~h}$ were analyzed by western blot assay. B) Semi-quantitative analysis of EGFR, p-EGFR, AKT, p-AKT, and HIF-1a expression. C) The effect of OSI intervention on the apoptosis rate of NCI-H1975 cells, NCI-H1975/OSIR cells, and NCI-H1975/OSIR-h cells. D) The statistical analysis of the apoptosis rate. E) The expression level of Bax and Bcl-2 in parental NCI-H1975 cells, NCI-H1975/OSIR cells, and NCI-H1975/OSIR-h cells treated with or without OSI $(0.5 \mu \mathrm{M})$ for $72 \mathrm{~h}$ were analyzed by western blot assay. F) Semi-quantitative analysis of Bax and Bcl-2 expression. ${ }^{*} \mathrm{p}<0.05$; ${ }^{*} \mathrm{p}>0.05$ 


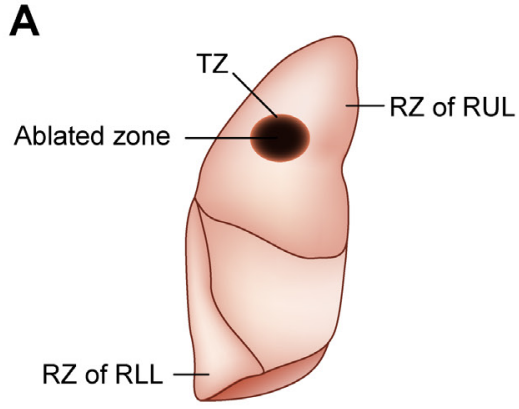

B

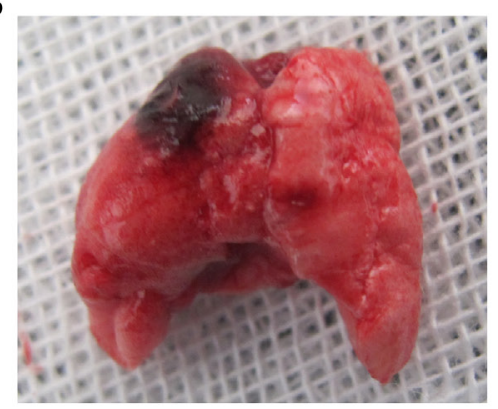

C

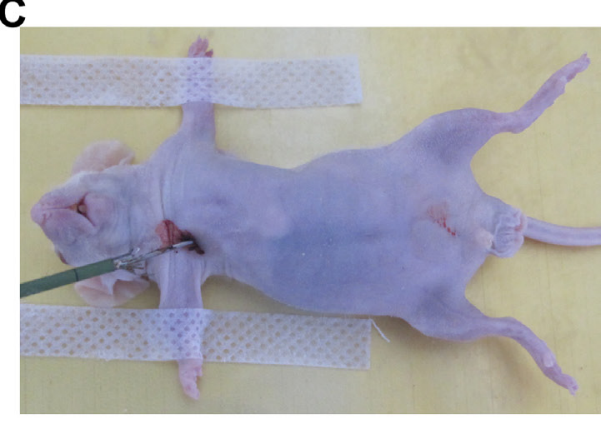

$\mathbf{F}$

Apoptosis rate in RZ and TZ

$\square$ Control group $\square$ OSI group

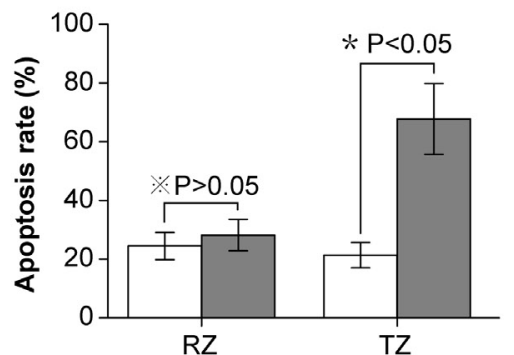

Figure 5. Sensitivity of NCI-H1975/OSIR cell micrometastases to OSI is increased in the transition zones following RFA treatment. A, B) After anesthesia, the mice underwent right upper lobe puncture treatment. The depth of needle percutaneous puncture was $0.5 \mathrm{~cm}$, and the necrotic ablation area formed was $0.3-0.5 \mathrm{~cm}$ in diameter. C) TZ was defined as the area stretching $2 \mathrm{~mm}$ outside the necrotic central zone. RZ was defined as the remaining part of the lung tissue and included the RZ of the right lung upper lobe (RUL) or the RZ of the right lung lower lobe (RLL) in this study. D) Following RFA treatment, tumor growth was expressed as the PRA in the TZ and RZ. E, F) The apoptosis rate in the TZ and RZ was measured using a Tunnel staining assay. The brown stained cells are apoptotic cells, and semi-quantitative analyses of apoptosis rates were measured by performing counts of 10 random fields (Scale bar: $200 \mu \mathrm{m}) .{ }^{*} \mathrm{p}<0.05 ;{ }^{*} \mathrm{p}>0.05$

Sensitivity of NCI-H1975/OSIR cell micrometastases to OSI was increased in the transition zones following RFA treatment. All mice were anesthetized and subjected to RFA treatment in the right upper lobe (RUL). The depth of needle percutaneous puncture was $0.5 \mathrm{~cm}$ and this formed the ablation area (Figures 5A, 5B). With thermal ablation, the TZ in the RUL and RZ in the RUL or right lower lobe (RLL) exhibited a different microenvironment, representing a different region of recurrence (Figure 5C). In the RFA group, it was found that the PRA value in the TZ was much higher than that in the RZ $(p<0.05$; Figure $5 D)$, indicating that the thermal effect generated by RFA treatment could induce the proliferation of metastases formed by NCI-H1975/OSIR cells in the TZ. However, no differences in the PRA values of the RZ without thermal influences were observed between the RFA group and the RFA + OSI group ( $p>0.05$; Figure $4 \mathrm{D}$ ). Besides, PRA values of the TZ in the RFA group were significantly decreased compared with the RFA + OSI group ( $<0.05$; Figure 5D). The above findings indicated that RFA treatment could increase the sensitivity of NCI-H1975/OSIR cell micrometastases to OSI, and OSI intervention could effectively inhibit local recurrence in the $\mathrm{TZ}$ around the ablation zone. The thermal effects generated by RFA overcame NCI-H1975/OSIR cell micrometastases resistance to OSI. In addition to inhibiting the proliferation of micrometastases in the TZ, it was proved that OSI could induce the apoptosis of NCI-H1975/OSIR cells in this area $(\mathrm{p}<0.05)$. However, in the RZ, there were little differences in the apoptosis of NCI-H1975/OSIR cells after OSI intervention ( $p>0.05$; Figures $5 \mathrm{E}, 5 \mathrm{~F})$. This demonstrated that the thermal effect generated by RFA facilitated OSI-mediated apoptosis of NCI-H1975/OSIR cells and inhibited the local recurrence in the TZ. Additionally, the survival and complication of control, RFA, and RFA + OSI mice were recorded (data not shown). It was demonstrated that the survival of the RFA + OSI group (58.29 $\pm 16.7 \mathrm{~d}$ ) was significantly longer than that in both the RFA group $(32.28 \pm 14.97 \mathrm{~d}, \mathrm{p}<0.001)$ and the control group $(21.41 \pm 9.82 \mathrm{~d}, \mathrm{p}<0.001)$, suggesting that the combination of RFA and OSI significantly improved the treatment efficacy of lung cancer. Moreover, complication or death was not observed in RFA or RFA+OSI treated mice in this study (data not shown).

The EGFR/PI3K/AKT pathway regulated the sensitivity of NCI-H1975/OSIR cell micrometastases to OSI. In this study, EGFR, p-EGFR, AKT, p-AKT, and HIF-1a protein expression levels in the $\mathrm{TZ}$ were upregulated compared 
with the RZ. After treatment with OSI, the expression of these proteins was significantly inhibited in the TZ $(\mathrm{p}<0.05)$. However, OSI treatment had little effect on protein expression of EGFR, p-EGFR, AKT, p-AKT, and HIF-1a in the RZ ( $p>0.05$; Figures $6 \mathrm{~A}, 6 \mathrm{~B}$ ). It was also found that the numbers of the micrometastases marked with CD34 in the TZ were much higher than those in the RZ. OSI could inhibit the CD34 expression heavily in the TZ but not in the $R Z$ ( $p<0.05$; Figures 6C, 6D), indicating that thermal effects generated by RFA might induce the sensitivity of micrometastases in the TZ to OSI through the EGFR/PI3K/AKT/HIF-1a signaling pathway.

\section{Discussion}

Although EGFR-TKIs initially produce effective responses in lung cancer patients with active EGFR mutation, most patients experience drug resistance after approximately 12 months of the treatment. A secondary mutation of T790M is associated with half of the acquired resistance cases [17, 18]. OSI (AZD9291) is an oral, CNS-active, third-generation EGFR-TKI that targets EGFR TKI-sensitizing mutations and T790M mutation [19]. Due to the occurrence of resistance to OSI, identification of possible resistance mechanisms and development of effective strategies are necessary [13]. The proliferation and viability of tumor cells were induced by certain growth-promoting signal pathways [20]. Especially, apoptosis was affected by anti-apoptotic and pro-apoptotic proteins, and the induction of apoptosis was usually accompanied by the decreased Bcl-2 expression [21] and increased Bax expression [22]. In this study, we established an OSI-resistant cell line (NCI-H1975/OSIR) and measured its viability and apoptosis, and suggested that OSI could inhibit the viability and induce the apoptosis of NCI-H1975 cells with a T790M mutation in EGFR and NCI-H1975/OSIR-h cells via stimulating Bcl-2 expression and reducing Bax-1 expression.

Patient resistance to OSI has been reported, and several resistance mechanisms such as a C797S mutation in EGFR,

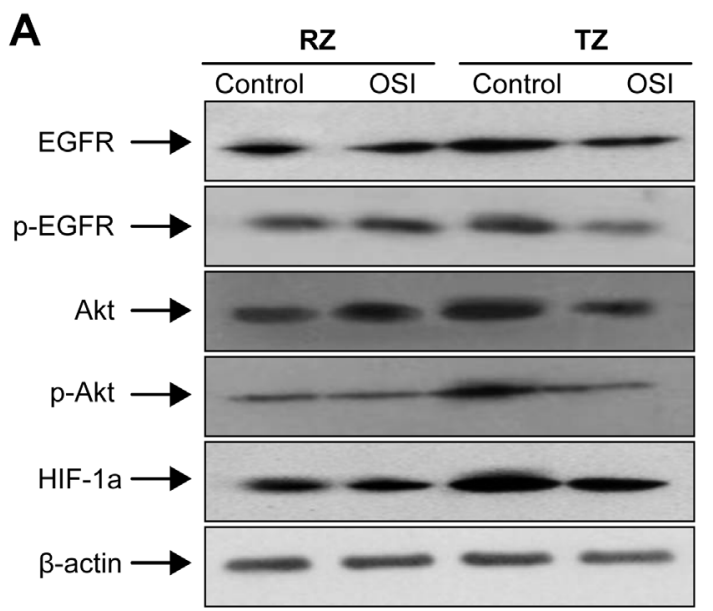

B

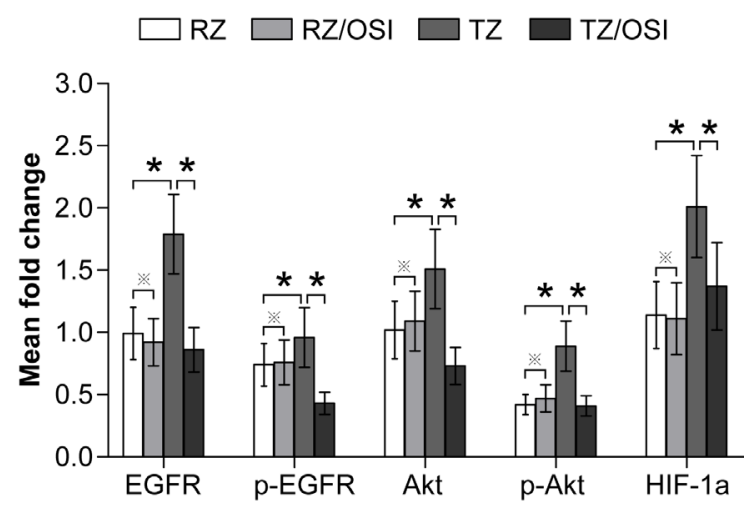

C

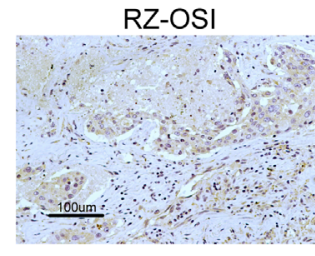

$\mathrm{RZ}$

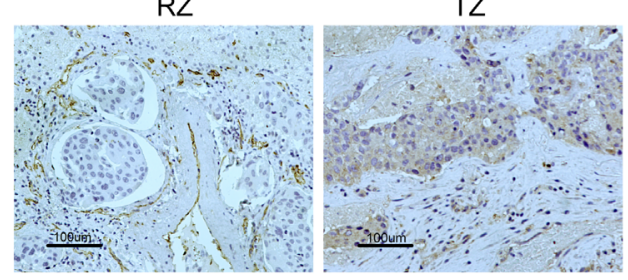

TZ-OSI

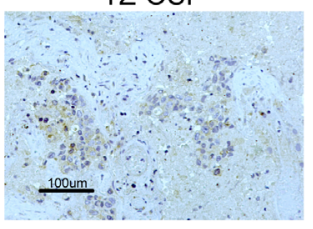

TZ
D

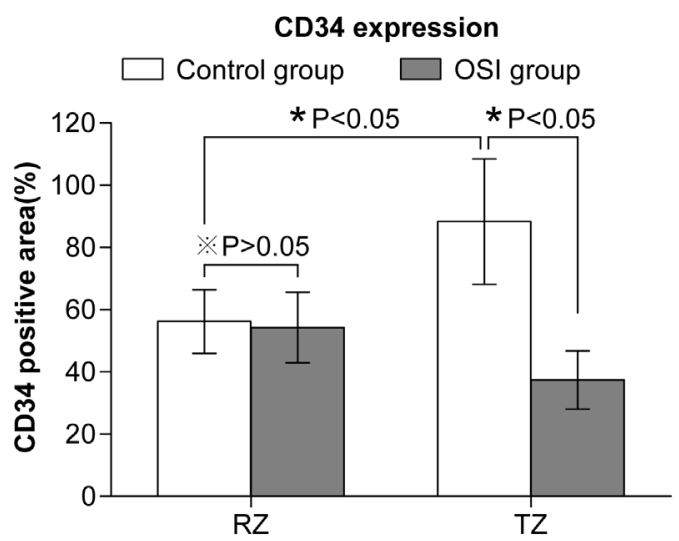

Figure 6. The EGFR/PI3K/AKT pathway regulates the sensitivity of NCI-H1975/OSIR cell micrometastases to OSI. A) Protein expression of EGFR, p-EGFR, AKT, p-AKT, and HIF-1a in the TZ and RZ treated with or without OSI ( $5 \mathrm{mg} / \mathrm{kg})$ was analyzed by western blot assay. B) Semi-quantitative analysis of EGFR, p-EGFR, AKT, p-AKT, and HIF-1a expression was done using ImageJ software. C) The numbers of new microvessels marked with CD34 expression in the TZ and RZ were detected by immunohistochemistry analysis and quantified by performing counts of 10 random fields (Scale bar: $100 \mu \mathrm{m})$. D) Semi-quantitative analysis of CD34 expression was conducted. ${ }^{*} \mathbf{p}<0.05 ;{ }^{*} \mathbf{p}>0.05$ 
MET activation, and a RAS mutation have been identified $[14,23]$. Unfortunately, no effective drugs or therapy strategies are currently approved for OSI-resistant NSCLC patients. An EGFR allosteric inhibitor, EAI045, was found to have selectivity toward the $\mathrm{C} 797 \mathrm{~S}$ mutant $\left(\mathrm{IC}_{50}=3 \mathrm{nM}\right)$, but the study of EAI045 remains in experimental stages [24]. Further identification of the resistance mechanisms of OSI in NSCLC patients is urgently needed for the development of new therapeutic strategies. In the present study, we examined the OSI resistance mechanisms in NCI-H1975/OSIR cells, which include inhibition of EGFR expression. Furthermore, the expression level of protein AKT and HIF-1a on downstream signaling pathways is decreased, which might be associated with the downregulated proliferation activity and viability of NCI-H1975/OSIR cells compared with parent cells [25]. Loss of EGFR has been identified as a resistance mechanism for the first-generation EGFR inhibitor gefitinib [26]. With this resistance mechanism, patients might no longer benefit from EGFR-TKIs or EGFR antibody therapy. A previous study demonstrated that the loss of the T790M mutation is another OSI resistance mechanism [14]. This study showed that T790M mutation levels are significantly decreased in the parental NCI-H1975/OSIR cells. However, thermal effects generated by RFA increase T790M mutation levels. The highest T790M mutation level and OSI sensitivity are observed in the $47^{\circ} \mathrm{C}$ heat-adapted NCI-H1975/OSIR subline, suggesting that the RFA thermal effects overcome the resistance to OSI by increasing T790M mutation levels.

RFA is becoming an accepted treatment for primary lung cancer in patients who are not suitable for subsegmental resection or lobectomy [27]. Compared to radiotherapy and chemotherapy, RFA focuses exclusively on the tumor area without causing any damage to the surrounding normal tissue. Further, RFA is superior to surgical treatment as being minimally invasive. In advanced lung cancers such as small cell lung cancer (SCLC), RFA also can be used as a palliative treatment with maximal effects [28]. However, recurrence after RFA usually occurs in the TZ, which is located at the margin of the ablation zone [29]. In this area, residual lung cancer cells may acquire thermotolerance and transform into a heat-adapted subtype. Some studies have demonstrated that, compared to parental lung cancer cells, heat-adapted subtypes are prone to proliferation, leading to recurrence. In addition, the angiogenic potential induced by hyperthermia following RFA also plays a role in the rapid growth of this subtype [30]. Some scholars refer to this as "malignant transformation" [31]. In the present study, we found that the proliferation of NCI-H1975/OSIR cells changes due to exposure to heat stress, especially in $47^{\circ} \mathrm{C}$-adapted cells. The sensitivity of the NCI-H1975/OSIR heat-adapted sublines to OSI is significantly enhanced compared to parental NCI-H1975/OSIR cells. Real-time PCR analysis showed that the T790M mutation level of the heat-adapted subtype cells is increased. In vivo, the residual tumor in the TZ is more sensitive to OSI than the tumor micrometastases without RFA treatment. These results suggest that the T790M mutation is closely related to OSI sensitivity, and thermal stimulation of RFA can induce the upregulation of T790M mutation, resulting in the increases in the sensitivity of lung cancer cells to OSI treatment. Activated EGFR can phosphorylate a range of substrates that results in the activation of multiple important downstream-signaling pathways within the cells, including the RAS-RAF-MEK-ERK pathway and the PI3K-AKT-mTOR pathway [32]. Considering the potential role of the EGFR/PI3K/AKT signaling pathway in HIF-1a expression, we wanted to better understand the involvement of EGFR/PI3K/AKT/HIF-1a in the stability regulation of tumor growth. In our previous study, the accelerated tumor growth in the TZ was reported to be induced by HIF-1a [15]. Another study showed that RFA causes profound hypoxia in the TZ [33]. The RFA-induced hypoxia can provide a growthstimulating microenvironment for the surviving tumor cells, which are transformed into heat-adapted subtypes [34]. AKT and HIF-1a are two major downstream proteins of the EGFR pathway, and inhibition of the EGFR pathway can decrease expression levels of p-AKT, total AKT, and HIF-1a [35, 36]. HIF-1a, a transcriptional factor induced by hypoxia, regulates multiple biological processes, including angiogenesis, cell proliferation, and migration [37]. We previously found that HIF-1a can regulate the expression of multiple cytokines and promote the proliferation and angiogenesis potential of lung cancer [38]. In this study, OSI decreases HIF-1a expression in the heat-adapted subtype through inhibition of EGFR. Clinical studies demonstrated that the blockade of EGFR rapidly decreases HIF-1a in advanced-stage NSCC [39]. In addition, we also found that the PI3K/AKT pathway is inhibited after the EGFR blockade. The PI3K/AKT pathway is involved in multiple biological processes of lung cancer, such as angiogenesis and proliferation, by stabilizing and upregulating HIF-1 a expression [40]. Following the blockade of the $\mathrm{PI} 3 \mathrm{~K} / \mathrm{AKT}$ pathway by OSI, residual lung cancer cells in the TZ exhibits a higher apoptosis rate. The angiogenesis potential is an important factor that induces the proliferation of the tumor. HIF-1a has been shown to play an important role in regulating the angiogenic potential of the tumor. OSI treatment inhibits the angiogenic potential of the micrometastases in the TZ by decreasing HIF-1a expression. Taken together, OSI can effectively block the EGFR/PI3K/AKT/HIF-1a pathway of residual heat-adapted lung cancer cells around the ablated zone. OSI inhibits the proliferation and angiogenesis potential, and induces apoptosis, thus leading to the reduced recurrence of NSCLC.

In summary, the results of this study demonstrate that thermal stimulation generated by RFA can significantly upregulate the sensitivity of NCI-H1975/OSIR cells to OSI. At the same time, OSI inhibits the local recurrence of lung cancer following RFA treatment. RFA combined with OSI might be an effective comprehensive therapy for the clinical treatment of OSI-resistant NSCLC. Nevertheless, clinical trials are needed in the future to verify our findings. 
Acknowledgments: We would like to thank the Research Center of the First Affiliated Hospital of Anhui Medical University and Laboratory Animal Center of Anhui Medical University for providing technical assistance. We would like to thank the Duoease Scientific Service Center for excellent language editing service and suggestions for figure revision. The present study was supported by the Natural Science Foundation of Guangdong Province (Grant No. 2018A0303130247).

\section{References}

[1] FERLAY J, SHIN HR, BRAY F, FORMAN D, MATHERS C et al. Estimates of worldwide burden of cancer in 2008: GLOBOCAN 2008. Int J Cancer 2010; 127: 2893-2917. https:// doi.org/10.1002/ijc.25516

[2] MOHAMMED TL, CHOWDHRY A, REDDY GP, AMOROSA JK, BROWN K et al. ACR Appropriateness Criteria ${ }^{\circ}$ screening for pulmonary metastases. J Thorac Imaging 2011; 26: W1-3. https://doi.org/10.1097/RTI.0b013e3182010bf9

[3] VARELA G, THOMAS PA. Surgical management of advanced non-small cell lung cancer. J Thorac Dis 2014; 6: S217223. https://doi.org/10.3978/j.issn.2072-1439.2014.04.34

[4] SCHREINER W, SEMRAU S, FIETKAU R, SIRBU H. [Oligometastatic non-small cell lung cancer- surgical options and therapy strategies.] Zentralbl Chir 2014; 139: 335 341. https://doi.org/10.1055/s-0034-1368233

[5] YU Q, JIANG D, LI Y. [Current Status and Prospect of T790M Mutation in Non-small Cell Lung Cancer.] Zhongguo Fei Ai Za Zhi 2017; 20: 199-204. https://doi.org/10.3779/j. issn.1009-3419.2017.03.09

[6] SOEJIMA K, YASUDA H, HIRANO T. Osimertinib for EGFR T790M mutation-positive non-small cell lung cancer. Expert Rev Clin Pharmacol 2017; 10: 31-38. https://doi.org/ 10.1080/17512433.2017.1265446

[7] ERCAN D, CHOI HG, YUN CH, CAPELLETTI M, XIE $\mathrm{T}$ et al. EGFR Mutations and Resistance to Irreversible Pyrimidine-Based EGFR Inhibitors. Clin Cancer Res 2015; 21: 3913-3923. https://doi.org/10.1158/1078-0432.CCR-14-2789

[8] DE BAERE T, FAROUIL G, DESCHAMPS F. Lung cancer ablation: what is the evidence? Semin Intervent Radiol 2013; 30: 151-156. https://doi.org/10.1055/s-0033-1342956

[9] GOLDBERG SN, GAZELLE GS, COMPTON CC, MCLOUD TC. Radiofrequency tissue ablation in the rabbit lung: efficacy and complications. Acad Radiol 1995; 2: 776784. https://doi.org/10.1016/s1076-6332(05)80852-9

[10] WAN J, WU W, ZHANG, R. Local recurrence of small cell lung cancer following radiofrequency ablation is induced by HIF1alpha expression in the transition zone. Oncol Rep 2016: 1297-1308. https://doi.org/10.3892/or.2015.4541

[11] GANG G, HONGKAI Y, XU Z. Sorafenib combined with radiofrequency ablation in the treatment of a patient with renal cell carcinoma plus primary hepatocellular carcinoma. J Cancer Res Ther 2015; 11: 1026. https://doi.org/10.4103/09731482.150405

[12] XU M, XIE X, XIE XY, XU ZF, LIU GJ et al. Sorafenib suppresses the rapid progress of hepatocellular carcinoma after insufficient radiofrequency ablation therapy: An experiment in vivo. Acta Radiol 2013; 54: 199-204. https://doi. org/10.1258/ar.2012.120249
[13] TANG Z, KANG M, ZHANG B, CHEN J, FANG $\mathrm{H}$ et al. Advantage of sorafenib combined with radiofrequency ablation for treatment of hepatocellular carcinoma. Tumori 2017; 103: 286-291. https://doi.org/10.5301/tj.5000585

[14] TANG ZH, JIANG XM, GUO X, FONG CM, CHEN X et al Characterization of osimertinib (AZ D9291)-resistant nonsmall cell lung cancer NCI-H1975/OSIRcell line. Oncotarget 2016; 7: 81598-81610. https://doi.org/10.18632/oncotarget. 13150

[15] THRESS KS, PAWELETZ CP, FELIP E, CHO BC, STETSON D et al. Acquired EGFR C797S mutation mediates resistance to AZD9291 in non-small cell lung cancer harboring EGFR T790M. Nat Med 2015; 21: 560-562. https://doi org/10.1038/nm.3854

[16] NIJKAMP MW, VAN DER BILT JD, DE BRUIJN MT, MOLENAAR IQ, VOEST EE et al. Accelerated perinecrotic outgrowth of colorectal liver metastases following radiofrequency ablation is a hypoxia-driven phenomenon. Ann Surg 2009; 249: 814-823. https://doi.org/10.1097/ SLA.0b013e3181a38ef5

[17] KIM ES. Olmutinib: First Global Approval. Drugs 2016; 76: 1153-1157. https://doi.org/10.1007/s40265-016-0606-z

[18] RICCIUTI B, BAGLIVO S, PAGLIALUNGA L, DE GIGLIO A, BELLEZZA G et al. Osimertinib in patients with advanced epidermal growth factor receptor T790M mutation-positive non-small cell lung cancer: rationale, evidence and place in therapy. Ther Adv Med Oncol 2017; 9: 387-404. https://doi. org/10.1177/1758834017702820

[19] ZHANG K, YUAN Q. Current mechanism of acquired resistance to epidermal growth factor receptor-tyrosine kinase inhibitors and updated therapy strategies in human nonsmall cell lung cancer. J Cancer Res Ther 2016; 12: C131C137. https://doi.org/10.4103/0973-1482.200613

[20] HANAHAN D, WEINBERG RA. Hallmarks of cancer: the next generation. Cell 2011; 144: 646-674. https://doi. org/10.1016/j.cell.2011.02.013

[21] XIA Y, XIA H, CHEN D, LIAO Z, YAN Y. Mechanisms of autophagy and apoptosis mediated by JAK2 signaling pathway after spinal cord injury of rats. Exp Ther Med 2017; 14: 1589-1593. https://doi.org/10.3892/etm.2017.4674

[22] JIN C, ZHANG G, ZHANG Y, HUA P, SONG G et al. Isoalantolactone induces intrinsic apoptosis through p53 signaling pathway in human lung squamous carcinoma cells. PLoS One 2017; 12: e0181731. https://doi.org/10.1371/journal.pone. 0181731

[23] EBERLEIN CA, STETSON D, MARKOVETS AA, ALKADHIMI KJ, LAI $\mathrm{Z}$ et al. Acquired resistance to the mutant-selective EGFR inhibitor AZD9291 is associated with increased dependence on RAS signaling in preclinical models. Cancer Res. 2015; 75: 2489-2500. https://doi. org/10.1158/0008-5472.CAN-14-3167

[24] WANG S, SONG Y, LIU D. EAI045: The fourth-generation EGFR inhibitor overcoming T790M and C797S resistance. Cancer Lett 2017; 385: 51-54. https://doi.org/10.1016/j.canlet.2016.11.008

[25] LIU K, FANG C, SHEN Y, LIU Z, ZHANG M et al. Hypoxiainducible factor 1a induces phenotype switch of human aortic vascular smooth muscle cell through PI3K/AKT/AEG-1 signaling. Oncotarget 2017; 8: 33343-33352. https://doi. org/10.18632/oncotarget.16448 
[26] SEQUIST LV, WALTMAN BA, DIAS-SANTAGATA D, DIGUMARTHY S, TURKE AB et al. Genotypic and histological evolution of lung cancers acquiring resistance to EGFR inhibitors. Sci Transl Med 2011; 3: 75ra26. https://doi. org/10.1126/scitranslmed.3002003

[27] WANG Y, LI G, LI W, HE X, XU L. Radiofrequency ablation of advanced lung tumors: imaging features, local control, and follow-up protocol. Int J Clin Exp Med 2015; 8: 1813718143.

[28] BAISI A, RAVEGLIA F, DE SIMONE M, CIOFFI U. Palliative role of percutaneous radiofrequency ablation for severe hemoptysis in an elderly patient with inoperable lung cancer. J Thorac Cardiovasc Surg 2010; 140: 1196-1197. https://doi. org/10.1016/j.jtcvs.2010.01.049

[29] LANUTI M, SHARMA A, WILLERS H, DIGUMARTHY SR, MATHISEN DJ et al. Radiofrequency ablation for stage I non-small cell lung cancer: management of locoregional recurrence. Ann Thorac Surg 2012; 93: 921-927. https://doi. org/10.1016/j.athoracsur.2011.11.043

[30] WAN J, WU W. Hyperthermia induced HIF-1a expression of lung cancer through AKT and ERK signaling pathways. J Exp Clin Cancer Res 2016; 35: 119. https://doi.org/10.1186/ s13046-016-0399-7

[31] OBARA K, MATSUMOTO N, OKAMOTO M, KOBAYAS$\mathrm{HI} \mathrm{M}$, IKEDA $\mathrm{H}$ et al. Insufficient radiofrequency ablation therapy may induce further malignant transformation of hepatocellular carcinoma. Hepatol Int 2008; 2: 116-123. https:// doi.org/10.1007/s12072-007-9040-3

[32] KO B, PAUCAR D, HALMOS B. EGFR T790M: revealing the secrets of a gatekeeper. Lung Cancer (Auckl) 2017; 8: 147-159. https://doi.org/10.2147/LCTT.S117944
[33] KROEZE SG, VAN MELICK HH, NIJKAMP MW, KRUSE FK, KRUIJSSEN LW et al. Incomplete thermal ablation stimulates proliferation of residual renal carcinoma cells in a translational murine model. BJU Int 2012; 110: E281-286. https://doi.org/10.1111/j.1464-410X.2012.11261.x

[34] WAN J, WU W, HUANG Y, GE W, LIU S. Incomplete radiofrequency ablation accelerates proliferation and an https:// doi.org/10.3892/or.2016.4858giogenesis of residual lung carcinomas via HSP70/HIF-1 $\alpha$. Oncol Rep 2016; 36: 659-668.

[35] WANG B, JIANG H, WANG L, CHEN X, WU K et al. Increased MIR31HG lncRNA expression increases gefitinib resistance in non-small cell lung cancer cell lines through the EGFR/PI3K/AKT signaling pathway. Oncol Lett 2017; 13: 3494-3500. https://doi.org/10.3892/ol.2017.5878

[36] SWINSON DE, O'BYRNE KJ. Interactions between hypoxia and epidermal growth factor receptor in non-small-cell lung cancer. Clin Lung Cancer 2006; 7: 250-256. https://doi. org/10.3816/CLC.2006.n.002

[37] WAN J, MA J, MEI J, SHAN G. The effects of HIF-1a on gene expression profiles of NCI-H446 human small cell lung cancer cells. J Exp Clin Cancer Res 2009; 28: 150. https://doi. org/10.1186/1756-9966-28-150

[38] WAN J, CHAI H, YU Z, GE W, KANG N et al. HIF-1a effects on angiogenic potential in human small cell lung carcinoma. J Exp Clin Cancer Res 2011; 30: 77. https://doi. org/10.1186/1756-9966-30-77

[39] CARMELIET P, JAIN RK. Angiogenesis in cancer and other diseases. Nature 2000; 407: 249-257. https://doi. org/10.1038/35025220

[40] WAN J, CHE Y, KANG N, WU W. SOCS3 blocks HIF-1a expression to inhibit proliferation and angiogenesis of human small cell lung cancer by downregulating activation of Akt, but not STAT3. Mol Med Rep 2015; 12: 83-92. https:// doi.org/10.3892/mmr.2015.3368 